\title{
IMPROVING THE ART OF EDUCATION IN THE DAILY \\ ACTIVITIES OF A WALDORF TEACHER
}

\author{
Olena Mezentseva \\ ORCID https://orcid.org/0000-0001-8345-1154 \\ Junior Research Fellow of the Institute of Pedagogy at the National Academy of \\ Sciences of Ukraine
}

\begin{abstract}
The article discuss the question of the teacher's professional development in accordance to the modern education challenges. Waldorf Education is taken as an example of effective teachers' professional on-going development. Rudolf Steiner (1861-1925), an Austrian philosopher and thinker, a founder of the first Waldorf School (die Freie Waldorfschule) in Stuttgart (Germany) in 1919, considered education not just as a science but also as an art. He stated that the art of education could be brought to life "through observation and contemplation of the cosmos and its connection with the human being" [4]. Steiner gave certain practical advices in the teachers' training, practice and feedback to provide adequate follow-up support in order to create the teachers' learning communities. The article observes the initial training of Waldorf teachers in their daily activities that include weekly teachers' conferences, child observation and class observation exercises, artistic workshops, lectures, seminars etc. The discussed problem is an essential part within the wider context of education reforms in Ukraine.
\end{abstract}

Key words: teacher's professional development, Rudolf Steiner, Waldorf School, Waldorf Teacher.

Актуальність дослідження. Особистість педагога - проблема, яка є центром соціальних та наукових дискусій не одне століття. В. Андрущенко зазначає, що «підгрунтям моделювання педагогічного образу ідеального вчителя виступають філософські концепції про ідеал людини - мудрої, доброї та справедливої, здатної передати свої знання дітям, виховати у них високі духовні якості. В основі цього ідеалу містилися, послідовно змінюючи одне одного, роздуми про людину античних мислителів, філософів середніх віків, епохи Відродження, нового і новітнього часу, класичних та модернізаційних філософських систем». [1]

Сучасна вітчизняна наукова думка, глибоко осмислюючи проблему формування особистості сучасного вчителя (Н. Абашкіна, В. Андрущенко, I. Бех, С. Гончаренко, В. Гончаров, М. Євтух, Ю. Завалевський, І. Зязюн, В. Кремень, О. Савченко, С. Сисоєва, В. Огнев'юк, В. Чайка та ін.), визначила широкий спектр особистісних якостей педагога, компетентностей, кваліфікаційних вимог, моделей формування, складових педагогічної майстерності тощо. Нова гуманістична парадигма освіти базується на засадах 
демократії, людиноцентризму, педагогічної свободи [3], яку Рудольф Штайнер (1861-1925) відстоював на початку XX ст., будуючи Вальдорфську школу.

Виклад основного матеріалу. Важливим принципом вальдорфської педагогіки є ідея класного вчителя, духовного наставника, який супроводжує розвиток дитини та становлення іï особистості протягом 8 років, викладаючи якомога більше предметів. Узагальнюючи сучасні підходи щодо особистості й діяльності педагога та аналізуючи ідеї Р. Штайнера, [4, 5, 6, 7, 8], визначаємо «портрет вальдорфського вчителя», який, за задумом автора Вальдорфської школи, є вчитель-поліфункціоніст. Він\вона:

Вчитель-митець, який, реалізовуючи ідеї мистецтва виховання художньо, творчо вирішує педагогічні задачі;

Вчитель-духовний наставник, який власним моральним прикладом, природним авторитетом веде дитину до істинної свободи у іiї дорослому житті;

Вчитель-ерудит, який викладає більшість (або всі навчальні предмети), орієнтуючись на вік дитини, а не сповідує позицію фахівця окремого предмета;

Вчитель-терапевт, який педагогічними засобами зцілює фізичне та душевне дитини;

Вчитель-консультант, який поєднує психолого-педагогічний супровід не тільки дитини, я й усієї родини;

Вчитель, водночас сойіальний педагог, який дбаючи про індивідуальне, формує соціальні якості особистості;

Вчитель-менеджер, який дбає про соціальний організм школи, вправляючись в управління різними сферами шкільного життя.

Високі вимоги до ідеалу педагога на сьогодні зупиняють молодь у виборі цієї професії. Дослідники вальдорфської педагогіки зазначають, що, як правило, у Вальдорфську школу приходять люди, які мають життєвий дослід, які приводять до школи своїх власних дітей або ж самі заходяться у пошуках життєвого шляху. Працюючи у Вальдорфській школі, можна спостерігати, що більшість вчителів отримують другу педагогічну освіту, свідомо обираючи професію вчителя. 
Рудольф Штайнер у своїх лекціях та доповідях, зустрічах з педагогами, формуючи високий ідеал вальдорфського вчителя, дає конкретні поради щодо підготовки педагогів та удосконалення педагогічної майстерності. Австралійський дослідник А. Маззоне [9] узагальнив теоретичні аспекти підготовки вальдорфських вчителів та, проаналізувавши існуючий досвід з цієї проблеми, визначив основні компоненти теоретичної та практичної підготовки педагогів для роботи у Вальдорфських навчальних закладах, а саме:

1. Основи антропософії.

2. Теоретичні та практичні аспекти вальдорфської педагогіки (розвиток дитини, зміст і методи навчання).

3. Мистецтво (живопис, ліплення, музика)

4. Мистецтво мовлення, театр.

5. Мистецтво руху (евритмія, ботмерівська гімнастика, спорт, соціальні ігри).

6. Ремесла.

7. Шкільний менеджмент (теорія соціальної трикомпонентності суспільства, робота педагогічної колегії, формування соціальних відносин).

8. Предметно-просторова організація класної кімнати.

9. Педагогічна практика.

При цьому автор зазначає, що «Вальдорфські школи не обмежують своїх співробітників прийняттям виключно антропософії, проте очікують від них симпатії щодо ідей та цінностей вальдорфської педагогіки. Прийняття ідей Штайнера щодо природи людини, розвитку дитини та широких аспектів навчальної програми Вальдорфської школи можливе без занурення в детальний аналіз філософських ідей Штайнера». [9]

Велике значення у вальдорфській педагогіці приділяється «внутрішній роботі» вчителя. Узагальнюючи рекомендації Р. Штайнера та досвід колегіальної роботи вчителів різних Вальдорфських шкіл щодо самовдосконалення та саморозвитку, маємо наступні форми:

Педагогічні колегї (конференцї̈ за Штайнером) - регулярні, щотижневі (як правило щочетверга) зустрічі усіх педагогічних працівників школи. Метою 
таких зустрічей $є$, за рекомендаціями Штайнера, вивчення людинознавства, удосконалення педагогічної майстерності через спільну педагогічну роботу. Ці конференції є поточною вищзою школою для вчителів, постійно діючою педагогічною семінарією, де обговорюються фундаментальні питання педагогіки, методики та дидактики, психології, антропології розвитку, відбувається обмін практичним досвідом навчальної та виховної роботи, самонавчання, самовиховання та саморозвиток вчителів. Важливою умовою $є$ відкритість та свобода кожного учасника колегії: ніхто не має права дорікати чи критикувати, педагоги обмінюються не тільки досягненнями, а й невдачами, помилками чи проблемами. Р. Штайнер [6, 7] неодноразово говорив, що Педагогічна конференція (засідання педагогічної колегії) є «серцем», яке своєю «кров'ю» живить усю роботу школи.

Важливо зазначити, що такі педагогічні колегії мають свою структуру та складаються $з$ наступних компонентів:

Перша частина. Педагогічні читання - простір для саморозвитку в теоретичних підвалинах вальдорфської педагогіки. Філософські праці Р. Штайнера є непростими для опрацювання, а отже Педагогічні читання здійснюються за певною технологією, поволі, осмислюючи абзац за абзацом. Важливим у такій роботі є не просто приймати на віру слова Штайнера, інакше вони, стають «мертвими методичними рекомендаціями», що підкреслював автор педагогіки з самого початку, а ставити запитання, зрозуміти, внутрішньо перевірити, погодити з власною позицією або ж не погодитись і шукати відповідь.

Друга частина. Психолого-педагогічні колегї̈консиліуми «Розгляд дитини» - організаційна форма, в рамках якої відбувається розробка i планування психолого-педагогічного супроводу учня. Колегія-консиліум об'єднує інформацію про окрему дитину, якою володіють вчителі-предметними, класні керівники, шкільний медичний працівник, психолог, соціальний педагог, арт-терапевт, вихователь дитячого садка, який відвідувала дитина до школи, та ін. Такий розгляд дитини має свою чітку структуру та методику проведення, 
готується заздалегідь, як правило, класним вчителем (класним керівником), глибоко занурюючись у деталі, особливості розвитку дитини від народження. На основі цілісного бачення проблеми, розробляється загальна педагогічна стратегія психолого-педагогічних впливів.

Психолого-педагогічні колегї-консиліуми «Ретроспектива життєдіяльності класів» - організаційна форма, в рамках якої відбувається розробка i планування психолого-педагогічного супроводу визначених учнівських груп та класів. Колегія-консиліум об'єднує інформацію про окремий клас, ступінь (молодший, середній, старший) школи, якою володіють вчителіпредметними, класні вчителі, вчитель групи подовженого дня, психолог, соціальний педагог. На основі цілісного бачення проблеми розробляється загальна педагогічна стратегія роботи з класом.

Психолого-педагогічні колегії-консиліуми проводяться у ритмі чергування (через четвер, або ж за потребою чи домовленістю).

В залежності від потреб, можливостей, розміру педагогічної колегії в 2-й частині можуть проходити художні заняття (евритмія, живопис, співи, соціальні вправи тощо), обговорення методичних питань або питання, на яким працює школа протягом навчального року, тощо.

Третя частина. Організащійна. Тут обговорюються нагальні потреби школи: відбувається представлення нових вчителів, розробляються концепції шкільних свят, соціальних проектів, створюються робочі групи з вирішення окремих задач, конфліктних ситуацій тощо. Дана частина засідання Педагогічної колегії $\epsilon$ простором інформування та прийняття важливих організаційних рішень щодо життєдіяльності школи. На засідання для вирішення спільних завдань запрошуються представники Батьківського активу, педагоги інших шкіл та громадських об’єднань.

Педагогічні колегії класів. Проводяться у кожному класі 1 раз на чверть (за потребою зустрічі можуть бути більш регулярними). До складу такої колегії входять усі педагоги, які працюють в класі, психолог, терапевти. На таких засіданнях обговорюються вікові особливості учнів, тематичне наповнення 
навчального плану, погоджуються спільні проекти, розглядаються складні ситуації, індивідуальні ситуації учнів, розробляється загальна педагогічна стратегія роботи з класом.

Предметні методичні об’єднання. Завданням таких об'єднань є:

- актуалізація завдань предметів, що вивчаються, 3 позицій вальдорфської педагогіки,

- розробка окремих уроків;

- обмін власними методичними розробками та педагогічними знахідками;

- взаємовідвідування уроків, виховних заходів;

- організація різноманітних проектів, участь в заходах різного рівню;

- методичний супровід нових вчителів та епох класних вчителів спеціалістами;

- створення умов для методичного вдосконалення педагогічних працівників;

- висвітлення тематичної інформації.

Індивідуальні консультації організовуються за запитом педагогів у довільній формі.

Вільні педагогічні ініціативи - це простір для вільного обміну педагогічним досвідом та саморозвитку вчителів, відритий як для педагогів школи, так і для тих, кого цікавлять теми, що обговорюються (батьки, студенти вальдорфського семінару, колеги з інших шкіл). Така вільна ініціатива може бути присвячена дослідженню загально педагогічного питання, вивченню літератури, лекціям у контексті світоглядних питань тощо.

Художньо-практичні ініціативи - це простір для саморозвитку педагога через мистецтво, відритий як для педагогів школи, так і колег з інших шкіл, батьків, студентів вальдорфського педагогічного семінару (художні майстерні, живописні студії, архітектурні проекти тощо.)

творчі об’єднання - вільні ініціативи, простір для саморозвитку вчителя, відритий як для педагогів школи, так i для батьків, студентів 
вальдорфського педагогічного семінару. Такі об’єднання можуть створюватись для постановки п’єси до свята, концерту, творчого вечора тощо. Так, наприклад, традицією кожної Вальдорфської школи є постановка п’єси «Різдвяна гра», яка стає центральним дійством зимових свят. Акторам стають саме вчителі, батьки та друзі школи. Це завжди довгоочікувана подія. Незважаючи на те, що така вистава ставиться щороку, кожного разу уся спільнота з нетерпіння чекає на неї, адже кожного разу акторський склад змінюється, а це означає, що можна побачити у виставі свого вчителя чи свою маму.

Робочі зрупи створюються для організації свят, відкритих заходів, конференцій тощо, є тимчасовим об’єднанням педагогів для виконання поставленої задачі. В завдання такої групи входить педагогічне осмислення цілей заходу, виховне наповнення, складання плану або сценарію, розподіл обов'язків між усіма педагогами, звернення за допомогою до адміністрації, батьків тощо.

Методичний тижжень проводиться двічі на рік - в кінці навчального року (червень) та перед початком нового (серпень) й включає в себе наступні компоненти: педагогічні читання, аналіз життєдіяльності та психологопедагогічних особливостей класів (або ж планування року відповідно до вікових потреб учнів), опрацювання методичної теми, саморозвиток через художньо-практичну діяльність та соціальні ігри, обмін досвідом тощо. Така форма роботи передбачає щоденну інтенсивну роботу (з 9.00 до 16.00) та $\epsilon$ джерелом самовдосконалення, роботи 3 новими педагогами, самоаналізу та соціальної взаємодії вчителів.

Окрім зазначених вище форм організації методичної підтримки та саморозвитку вчителів на базі Вальдорфських шкіл організовують лекції та семінари з питань педагогіки, історії, культури тощо. Вчителі, як правило, щороку відвідують міжнародні семінари, конференції, конгреси 3 питань вальдорфської педагогіки, де створюється простір для міжнародного обміну 
досвідом. Часто школа сама стає організатором регіональних семінарів для підготовки вчителі для роботи у Вальдорфських навчальних закладів.

Так, скажімо, в Україні на сьогодні єдиною можливістю отримати цілісну підготовку 3 питань вальдорфської педагогіки $\epsilon$ Всеукраїнський вальдорфський педагогічний семінар, що проводиться ВГО «Асоціація вальдорфських ініціатив в Україні» за підтримки IAO (Міжнародна Асоціація Вальдорфської педагогіки в Центральній та Східній Європі). Базою даного постійно діючого семінару $є$ існуючі Вальдорфські школи України, Педагогічною колегією - вчителі Вальдорфських шкіл. Семінар працює у режимі очно-заочного навчання, 34 сесіями на рік, кожна з яких проводиться на базі однієї зі шкіл. На такі інтенсивні сесії приїжджають учасники з усієї України, що дозволяє використати ресурси навчальних закладів (досвідчені педагоги школи, викладачі мистецтв, приміщення, матеріали тощо) та запрошуються колеги з-за кордону, які мають досвід у викладанні людинознавчих предметів або ж досвідчені вальдорфські класні вчителі.

Висновки. Говорячи про вільну Вальдорфську школу, перш за все, мають на увазі свободу, яку має педагог у своїй педагогічній діяльності. «...Дуже важлива умова - свобода ініціативи педагога. <..> Ви можете побачити, як один i той самий предмет викладається в паралельних класах різними методами. Чому ми так чинимо? Тому що суттєвий елемент навчання індивідуальність вчителя. Урок може бути гармонійним тільки при живому i міцному контакті вчителя з усім класом», зазначав Р. Штайнер [7]. На думку автора Вальдорфської школи абстрактно можна скласти чудові навчальні програми, зовсім інша справа - реалізовувати їх, оскільки в житті з'являється елемент індивідуальності. Тож, маючи педагогічну свободу, вчитель працює в педагогічній колегії, яка захищає навчальний процес від анархії. Працюючи разом глибоко над педагогічними, методичними, діагностичними, терапевтичними проблемами, вчителі, розвиваючись самі, краще пізнають своїх колег, їхні сильні та слабкі сторони, якості характеру, особливості 
темпераменту. А отже, колегія може порадити, застерегти або навіть перешкодити прийняти невірне рішення, супроводжувати ті чи інші процеси.

Сьогодні, на нашу думку, прогресивним кроком в реформуванні системи освіти України стали такі нововведення в Законі України про освіту як академічна свобода та автономія навчального закладу, що за словами чинного Міністра освіти і науки України Л. Гриневич [2] «мають поліпшити умови праці вчителя за рахунок зменшення бюрократичного контролю, розширення академічних свобод і формування простору для творчої праці. Буде обмежено втручання державних органів і органів місцевого самоврядування в освітній процес». Вальдорфська педагогіка має вже майже столітній досвід впровадження цих положень Закону про освіту України.

\section{References}

1. Andrushchenko, V. \& Tabachek I. (2005). Formuvannia osobystosti vchytelia v suchasnych umovah [Formation of a teacher's personality in modern conditions]. Politychnyi menezhment ( 1 (10)), 58-69.

2. Do zakonu Ukrainy "Pro osvitu" [To the Law on Education of Ukraine] (2017, September 29) Retrived from: http://mon.gov.ua/activity/education/reforma-osviti/materiali-do-zakonu-ukrayinipro-osvitu.html

3. Kremen, V. (2001). Dopovid ministra isvity i nayku Ukrainy Vasylia Kremenia na II Vseukrainskomu zyizdi pratsivnykiv osvitu [Report of the Minister of Education and Science of Ukraine Vasyl Kremen at the Second All-Ukrainian Congress of Educators]. Pedahohichna hazeta, (10), 3-5.

4. Steiner, R. (1992). Allgemeine Menschenkunde als Grundlage der Pädagogik. (GA 293) RUDOLF STEINER VERLAG, Dornach / Schweiz.

5. Steiner, R. (1990). Erziehungskunst Methodisch-Didaktisches. (GA294) RUDOLF STEINER VERLAG. Dornach / Schweiz.

6. Steiner, R. (1991). Die Erneuerung der pädagogisch-didaktischen Kunst durch Geisteswissenschaft. (GA301) RUDOLF STEINER VERLAG. Dornach / Schweiz.

7. Steiner, R. (1989). Die pädagogische Praxis vom Gesichtspunkte geisteswissenschaftlicher Menschenerkenntnis. Die Erziehung des Kindes und jüngeren Menschen. (GA 306) RUDOLF STEINER VERLAG. Dornach / Schweiz.

8. Steiner, R. (1986). Die Methodik des Lehrens und die Lebensbedingungen des Erziehens. (GA308) RUDOLF STEINER VERLAG. Dornach / Schweiz.

9. Mazzone, A. (1999). Waldorf teacher education: the implications for teacher education of Rudolf Steiner's educational philosophy and its practice in Waldorf schools. (Dissertation). Adelaide University.

Translation of the Title, Abstract and References to the Author's Language

\section{Олена Мезенцева. Удосконалення мистецтва виховання в повсякденній діяльності вчителя Вальдорфської школи.}


У статті розглянуто питання професійного розвитку вчителя у відповідності до сучасних освітніх викликів. Автор розглядає вальдорфську педагогіку як приклад ефективної системи професійного розвитку вчителів. Рудольф Штайнер (1861-1925), австрійський філософ і мислитель, засновник Першої Вальдорфської школи (die Freie Waldorfschule) у Штутгарті (Німеччина) у 1919 р., розглядав освіту не лише як науку, а й як мистецтво. Він зокрема зазначав, що мистецтво виховання може бути реалізовано «шляхом спостереження та споглядання космосу та його зв'язку з людиною» [4]. Штайнер дав ряд практичних порад щодо навчання вчителів, педагогічної практики та системи зворотного зв'язку педагогів, задля забезпечення ефективної підтримки професійного розвитку вчителя та створення педагогічної спільноти, що навчається та розвивається. У статті упорядковано систему заходів щодо удосконалення мистецтва виховання у повсякденній діяльності вальдорфського вчителя. яка включає щотижневі педагогічні конференції, спостереження за дітьми та спостереження за класом, художні майстер-класи, лекції, семінари тощо. Представлена проблема є важливою частиною широкого контексту освітніх реформ в Україні.

Ключові слова: професійний розвиток вчителя, Рудольф Штайнер, Вальдорфська школа, вальдорфський вчитель.

\section{Література}

1. Андрущенко, В. \& Табачек, I. (2005). Формування особистості вчителя в сучасних умовах. Політичний менеджмент (1 (10)), 58-69.

2. До Закону України «Про освіту». (2017, вересень 29) Взято з: http://mon.gov.ua/activity/education/reforma-osviti/materiali-do-zakonu-ukrayini-pro-osvitu.html

3. Кремень, В. (2001). Доповідь міністра освіти і науки України Василя Кременя на II Всеукраїнському з'їзді працівників освіти. Педагогічна газета, (10), 3-5.

4. Steiner, R. (1992). Allgemeine Menschenkunde als Grundlage der Pädagogik. (GA 293) RUDOLF STEINER VERLAG, Dornach / Schweiz.

5. Steiner, R. (1990). Erziehungskunst Methodisch-Didaktisches. (GA294) RUDOLF STEINER VERLAG. Dornach / Schweiz.

6. Steiner, R. (1991). Die Erneuerung der pädagogisch-didaktischen Kunst durch Geisteswissenschaft. (GA301) RUDOLF STEINER VERLAG. Dornach / Schweiz.

7. Steiner, R. (1989). Die pädagogische Praxis vom Gesichtspunkte geisteswissenschaftlicher Menschenerkenntnis. Die Erziehung des Kindes und jüngeren Menschen. (GA 306) RUDOLF STEINER VERLAG. Dornach / Schweiz.

8. Steiner, R. (1986). Die Methodik des Lehrens und die Lebensbedingungen des Erziehens. (GA308) RUDOLF STEINER VERLAG. Dornach / Schweiz.

9. Mazzone, A. (1999). Waldorf teacher education: the implications for teacher education of Rudolf Steiner's educational philosophy and its practice in Waldorf schools. (Dissertation). Adelaide University. 